\title{
In search of an imagery of domestic objects in Chile (1860-1930) through Lira Popular broadsheets as a graphic and identity reference
}

\author{
Simoné Malacchini / Universidad de Chile / Santiago / Chile
}

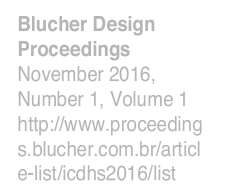

\begin{abstract}
One of the most important examples of identity graphics in Chile is the Lira Popular, a set of broadsheets printed in Chile (1860-1930) by popular poets who would report sensationalist news in décimas [ten-line stanzas], generally illustrated with an engraving; a largely urban phenomenon due to rural-urban migration and the resulting population growth in cities. Beyond the content of the broadsheets the image takes on relevance: the engravings reinforce a visual imagery where domestic objects, associated with the popular class, and consistent with the identity of these broadsheets, are represented and recognized as of part of a local identity. The following paper will approach material culture in Chile through a focus on objects of everyday use as seen in the Lira Popular, in order to elucidate from them a collective imagery and identity.
\end{abstract}

\section{Keywords}

Domestic imagery, household objects, material culture, visual culture, Chilean identity, broadsheets

\section{Introduction}

The following paper will delve into the images of household objects, present in the Lira Popular broadsheets, as a reference to a system of everyday objects that could form a collective imagery and identity. The Lira Popular will be used as a cultural object with a strong local identity in order to approach the material culture of the nineteenth and early twentieth centuries, in search of an imagery of objects in Chile.

In this regard, the following investigation seeks to contribute to the current lack of knowledge on the subject in Chile, with the Lira Popular as a gateway given its importance as a graphic and visual reference and signifier of local identity. To this end, the broadsheets will be analysed by contrasting with historical documentation: photographs, prints, travel accounts and studies of the time.

First, the Lira Popular will be presented according to its context and local identity; the broadsheets will then be analysed and the objects within presented; finally, this information will be compared with historical documents to clarify and verify a system of everyday objects.

\section{The Lira Popular: Context and identity value}

The Lira Popular is a loose set of broadsheets printed in Chile from approximately 1860 to 1930, within which sensationalist news events were generally reported, illustrating the most striking event with engravings. Written in décimas, the broadsheets were aimed at a mostly illiterate audience and made by rural popular poets, who brought a culture of oral tradition from the country to the city, based on popular chanted poetry.

The period of the Lira Popular is one of profound modernization and social change in Chile, a time of mass migration from rural areas to cities undergoing urbanization. After 1865, a migrant population arose which initially favoured the new mining region and great cities; by 1885 the migratory movement accelerated because of the crisis in the mining sector, the shutdown of the hacienda system, and the growing need for labour due to major modernization of the cities, which caused an increase in the urban population (Salazar, 2000). Due to rapid deruralisation, this population was relegated to second rate work, and thus stuck between its rural origins and its 'proletarian-industrial' destiny, stripped of its rural roots and yet not entirely at home in the developing city - a 

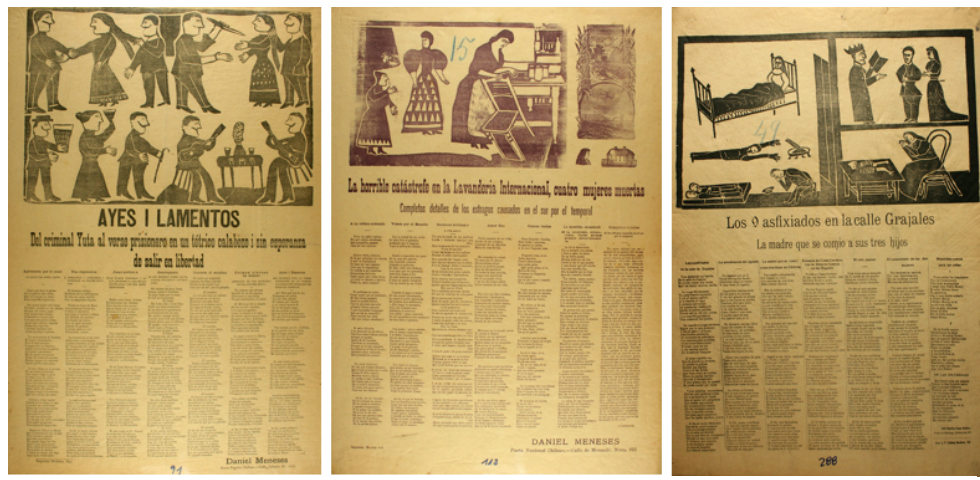

Fig. 1: Lira Popular broadsheets, from the "Archivo de Literatura Oral y Tradiciones Populares", Biblioteca Nacional de Chile, and "Archivo Andrés Bello", Universidad de Chile 'hybrid' group of peasants who were no longer peasants, but who did not want to abandon their traditions. In this way, the urban huaso [laborer or farmhand] needed something that would remind him of his origins so as to not feel uprooted in this new scenario. In this context, the Lira Popular arises as a cultural object that contributes to the transition carried out by the peasant who arrives in the city, materializing the oral tradition through print and its subsequent publication while connecting, at the same time, to the new reality of the city (Malacchini, 2015). The Lira Popular,

consistent with the audience to which it was addressed - as bearer of an oral tradition associated with a sense of 'origin', and a reporter of the events close to the reality where the audience saw itself portrayed - encouraged identification with the message it delivered as an active subject in the construction of a national identity. The topics reported form the image and collective unconscious of a social body in action, a mirror of Chilean idiosyncrasy: the manner of thinking about certain subjects and the feeling and life of the people. The broadsheets thus enable the construction of a social and collective imagery, forging allegiance for, and with, an audience of limited economic and cultural means, enabling access to a particular form of expression that allows it to participate of the city through varied recognizable codes: on the one hand, the décima, linked to oral culture; on the other hand, print, associated with the city itself.

In addition to the above, the upper class rejected any association with rural origins; coupled with a strong aspiration by the oligarchy to a European model, another identity bond is forged from the contrast between a ruling caste with a taste for the foreign (with a preference for French modes) and traditional or local customs. Thus, the Lira Popular represents this due to its origin, theme and imagery, and consequently would be a repository of an identity that comes from a tradition without further external influences, thus becoming an object considered to be "Chilean". Concerning this, besides the fact that Lira Popular is actually considered as a "Chilean object", in Latin America (specially in México and Brazil) exists similar examples of broadsheets, printed at the same period of time, that are also considered as a local graphic referents in its countries: a phenomenon that denotes a common identity, an imaginary associated to the entire region, "holder of an expression related to the popular sectors in each country, where the sense of 'popular' would be linked with a sense of origin and identity" (Malacchini, 2012).

Regarding the image found in the Lira Popular, it occupied a significant portion of the space of the broadsheet. Considering the high levels of illiteracy in Chile - by 1865 illiteracy was estimated at 83\% (Labarca, 1939) - the use of the image gains even greater relevance. Its primary function was likely to facilitate the understanding of the texts to an illiterate audience, but above this to draw attention to the broadsheet by making it more attractive. The image, which was usually a woodcut representing the most scandalous events, was used to portray scenes that were familiar both to the popular poet and to the audience to which it was directed. In this sense, the image identified its reader with a common and collective imagery representing everyday scenes, such as toasting, popular characters, canteens, and violent scenes, among others. The above is reinforced by the importance taken on by the use of woodcuts in the history of Chile, a widely-used means of reproduction especially in the beginning by a marginal sector, where the Lira Popular in particular enjoys a foundational status in the wood engraving tradition.

The identity value of the Lira Popular broadsheets, its décimas, but especially its engravings, has resulted in its use as a graphic reference where the identity value of the image becomes more relevant. The broadsheets became a platform for identity, where identity lies with the content of popular origin in association with the local, thus constituting a graphic identity based in popular culture (Malacchini, 2015).

\section{Household objects and their presence in the Lira Popular}

The presence of different objects, for the most part of household use, can be observed in the scenes illustrated in the Lira Popular broadsheets. Although the woodcuts are in rough strokes - far removed from the woodcuts seen in European broadsheets - the objects remain recognizable; the strokes confer the image an identifiable style that will 
be associated with an image of 'popular' origin (as opposed to 'finer'-lined clichés). In the broadsheet, in order to visualize a scene that must be recognizable to a largely illiterate audience, representation becomes crucial, an synthesis exercise of context that must relate to its public: the popular poet, or the engraver (who were not always the same person), must decide which objects should make up the scene to communicate, from the image, an identifiable action. In this way, through an economy of resources will be possible to discriminate the objects to make up the engraving, illustrating the essential and recognizable to build an image. This is reinforced by the vision of philosopher and psychologist William James (contemporary of the period studied): "Millions of items in the outward order are present to my senses which never properly enter into my experience. Why? Because they have no interest for me. My experience is what I agree to attend to. Only those items which I notice
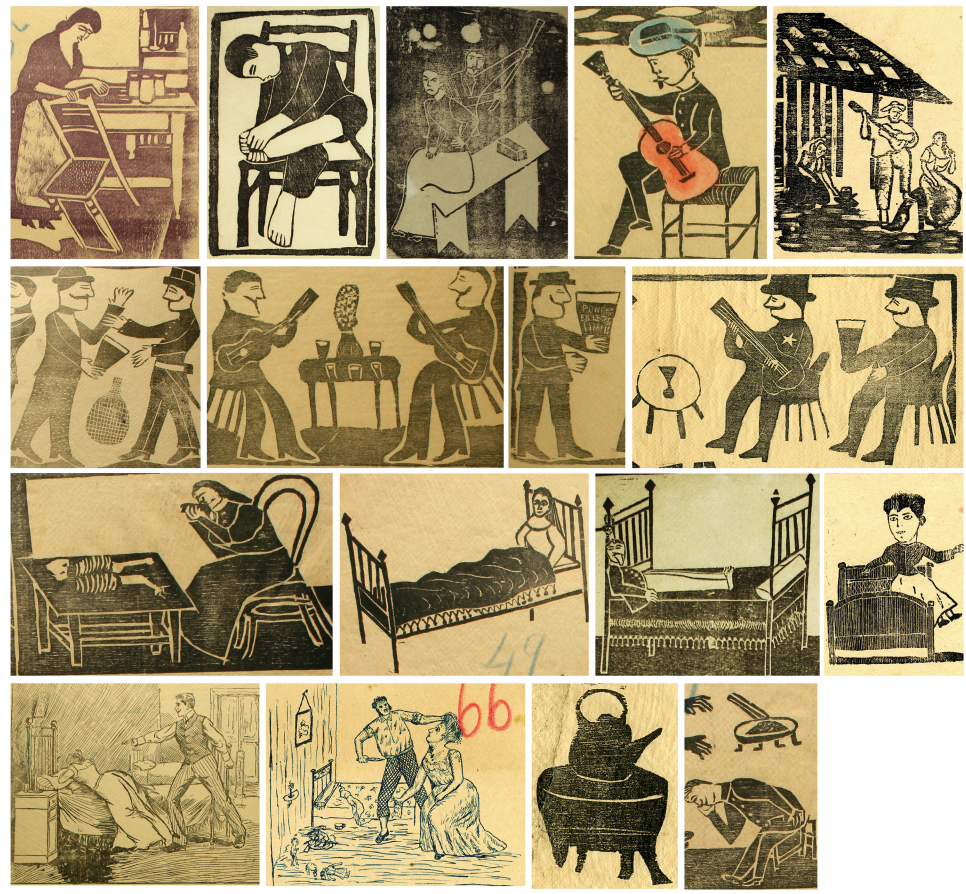

Fig. 2: Objects in the woodcuts of Lira Popular. In order: Chairs, bench, stool, the gallery outside an urban dwelling, glasses and cups, a toast, low table, beds, a bedroom and braziers with a teapot

shape my mind..." (Csikszentmihalyi \& Rochberg-Halton, 1981; James, 1890, p. 402). In the present case, care is given to selection of the main objects that could serve to build an imagery familiar to the audience. The objects on display are the objects of their immediate surrounding, which accompany them daily and to which attention is given, both through repetition and by virtue of being, for the most part, the few objects in their possession.

Thus, in the images we see a representation of chairs, stools, benches, low tables, beds, knives, braziers, teapots, musical instruments (the llanera harp, vihuela guitar and Chilean guitarrón), demijohns and, above all, different glass vessels. The latter is unsurprising given that at the time there was talk of alcoholism in farmhands and labourers, a problem signalled not only by the gentry, but also by the popular poets in their verses. The toast, which involved wine, beer or hard liquor, was part of a national tradition.

As regards the furniture, with the exception of beds (a metal bed is observed) the representation is wooden furniture denominated "rustic", where chairs and stools evidenced a seat of woven vegetable fibre (straw, wicker or cattail). The musical instruments, on the other hand, are precisely those in use today to play Chilean folkloric music (cueca or zarzuela at the time). The brazier, of simple form and made of iron or other metals, was a central object in the room: as well as serving to heat the room, it was where the water was boiled in the teapot for breakfast, as well as other meals, always within the confines of the 'bedroom'. Thus, all of these objects may well constitute a set of objects of everyday use associated with a local imagery.

Many of the scenes depicted in the broadsheets occur outside, as in the case of galleries or courtyards, which were usually a space adjoining the bedroom. For this segment of the population, most of whom were crowded in one room per family in conventillos [tenements] or urban ranches (De Ramón \& Gross, 1985), the gallery or the courtyard was the natural continuation of the room, the space where social life took place. This is where lunch was 'cooked' and shared with other residents, as well as being the stage of impromptu parties accompanied by the chilean guitarrón and the harp.

This is why, when speaking of 'domestic' objects, these are contextualized in a space that is not

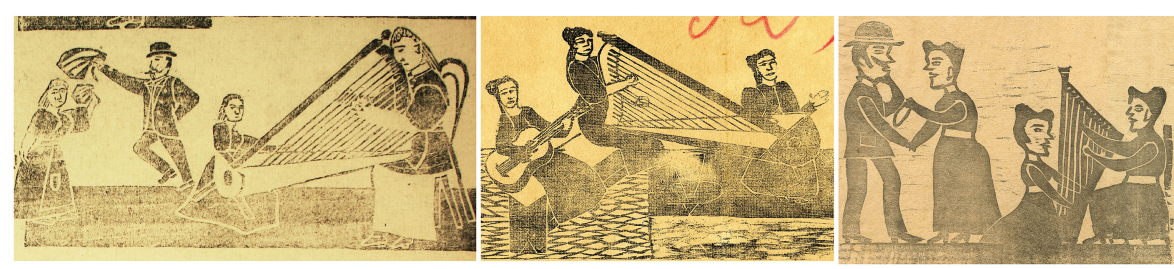

Fig. 3: Instruments in the woodcuts of Lira Popular. The llanera harp, guitarrón chileno, people dancing zarzuela exactly confined to a house as such: they are household objects subject to open and common areas, both outside and inside the room, which are in turn of 'hybrid' use. The chairs that are used in 


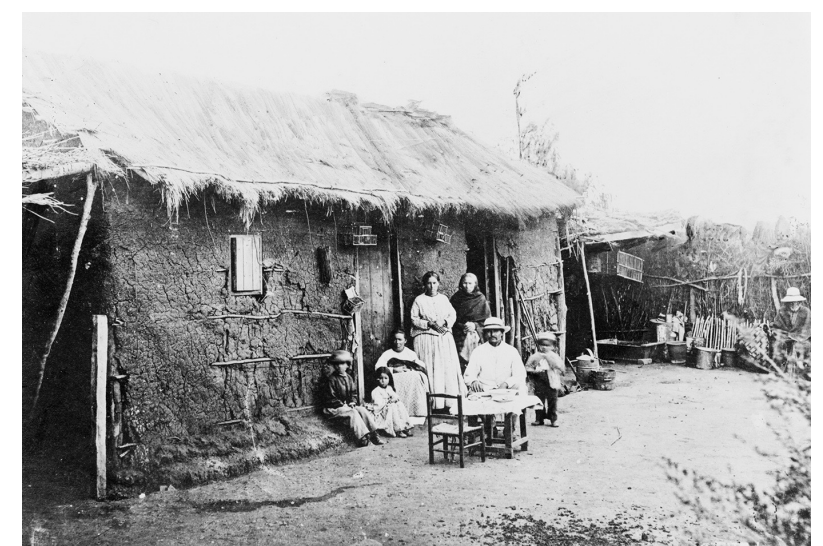

Fig. 4: A farm house in Chile. Pictured above: 'rustic' furniture, among others objects. Library of Congress emphasizing the construction of collective identity, in which the ecology of signs is further highlighted by focusing on a limited number of objects.

\section{Everyday objects: Identity imagery of a working class in information}

The objects defined above were compared with photographs and documents of the period in question, which coincided with the largest modernization of cities and main migratory movement in Chile. While it is impossible to find pictures of the inside of the houses, given that at the time photographs were normally reserved for the wealthy, whose home interiors were rarely photographed (much less those of common people), some photographs were found that portray life in tenements and some urban ranches, but only their courtyards and galleries. Here, the space is a centre of reunion: due to overcrowding, the domestic space had little choice but to expand to the collective space. We see in these common spaces the presence of largely the same objects portrayed in the broadsheets of the Lira Popular. The only object that is absent is the metal bed, which is usually limited to the private sphere. Many objects, especially furniture, resemble or are identical to the typology of those used in rural ranches. In this regard, some objects that are considered " could have derived from a peasant background, belying the rural origin of their owners. These are objects that relate to memory and nostalgia, a role linked to 'antique' objects as defined by Baudrillard: "(...) "Such is the role of antique objects, which always take on the meaning, in the context of the human environment, of an embryo or mother-cell." (Baudrillard, 1996, p. 84). Transitional objects that would serve as a bridge, in many respects, for labourers settled in the city to their rural origins, while staying within the urban context; contributing, as in the case of the Lira Popular, to making the transition from peasantry to a developing working class more bearable.
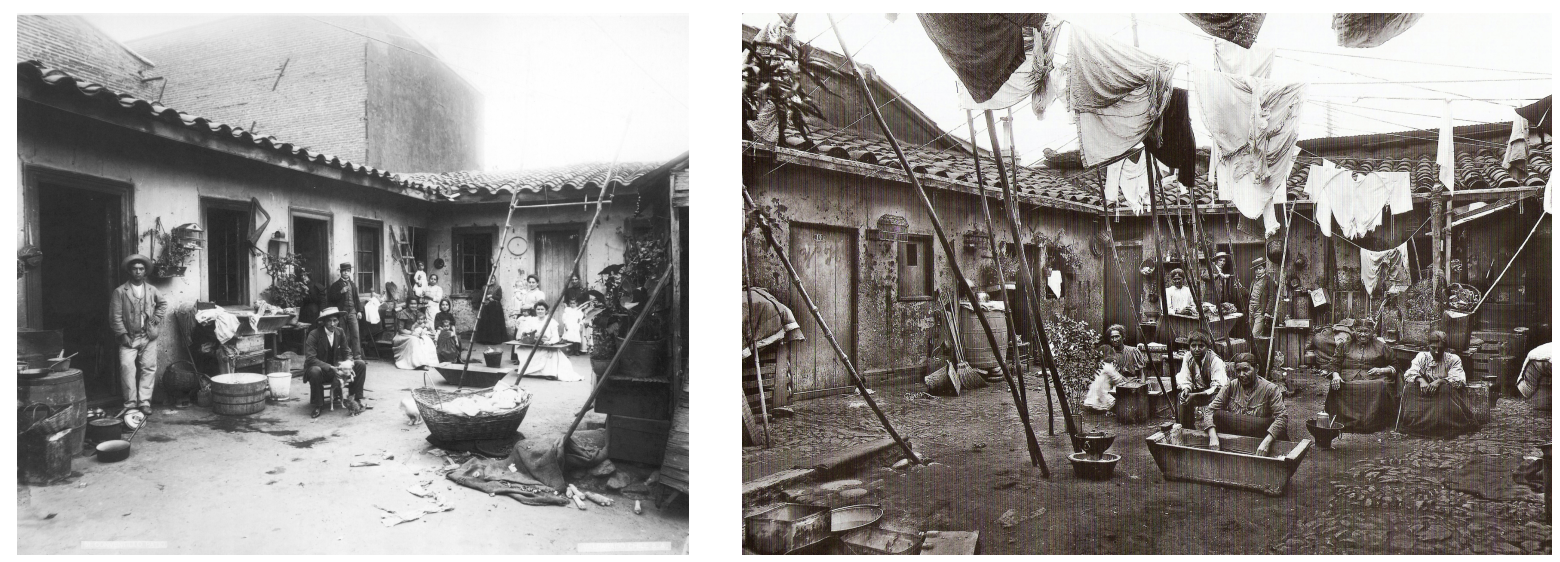

Fig. 5: Two photos of the courtyard inside of the tenements. Photo: Harry Olds, 1900, Valparaíso, Chile. Museo Histórico Nacional de Chile 

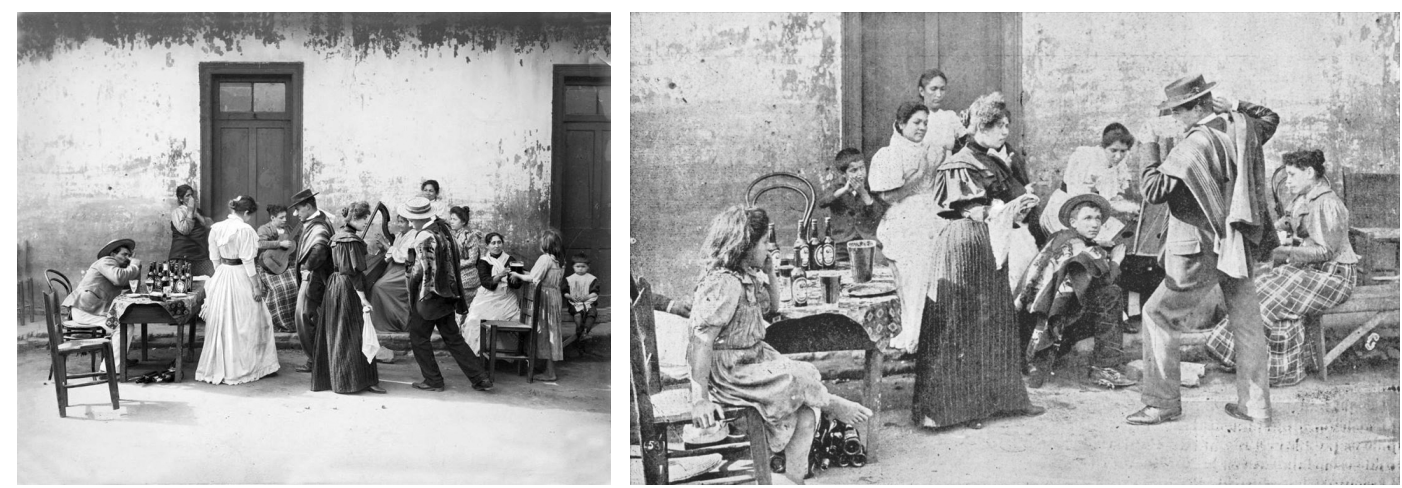

Fig. 6: Two photographs of a folkloric scene, the zamacueca dance. Harry Olds, 1900. Museo Histórico Nacional de Chile

A 1903 social study of a working class family (Eyzaguirre \& Errázuriz, 1903) reveals more details of life inside the rooms: nine family members lived in one space, several of whom would sleep in the same bed while the mother ironed clothes, leaving the brazier on until it would extinguish on its own. Breakfast and the evening meal were made in the same room, with space for a hen house in the corner. The room lacked ventilation and natural lighting. The goods that the family possessed are also listed in the study, many of which coincide with those observed in the broadsheets, drawing attention to the objects that appear under the category of furniture (tables, iron beds, chairs, benches, nightstand, mirror, wool and straw mattresses, bedding, cages, among others) and utensils (brazier, a portable furnace, clay pots, buckets, large and small teapots, plates, cups, bowls, spoons, forks, knives and a large glass). The above-mentioned objects are defined as a few articles of "first necessity, very poor and in disrepair" (Eyzaguirre \& Errázuriz, 1903), corresponding to objects of everyday use that, given their scarcity - being limited and quantifiable - take on importance, thus reinforcing the imagery they create.

In contrast to the above, the system of objects of the ruling class aspired to objects governed by European fashion: Louis XV furniture, large dining tables and halls of mirrors. The Chilean upper class had identified itself with the foreign, with the desire to belong to a great Paris or London. In an almost opposite place, the system of objects associated with an imagery of the urban popular class from the country, it would connect with a sense of oral/rural origin. Here, the objects become signifiers of identity, taking on a leading role in a historic moment in Chilean society undergoing transformation.

\section{Conclusion}

Analysis of the Lira Popular as a cultural object and bearer of local identity is, in itself, a gateway to the study of material culture at the end of the nineteenth century and early twentieth century in Chile. In this manner, beginning with the observation of the set of household objects represented in the broadsheets, it questions their possible identity value and how they could contribute to a collective imagery and identity.

The studied objects are as transitional and 'hybrid' as the context in which they are located: the labourer, who is neither a peasant nor city dweller, sees both the Lira Popular and the objects it represents as a bridge between modernization of the city and the rural nature of the country.

In this way, these objects propose a collective imagery tied to a common language of objects, allowing, in turn, the construction of an imagery recognizable by an audience that, while illiterate, is assumed to be object-literate. Thus, the audience is illiterate people who read, beyond the text, the image on the broadsheet: the represented objects communicate from a common language of images to a social group that shares the same origins. This language, which articulates and strengthens itself from community experience, conveys an imagery that determines a recognizable common identity.

This identity is built upon the community experience that is reflected in the domestic space, which expands to the common area of the dwelling. It is in this place where the 'reading' of objects becomes important: these are experiences that are shared by a large part of the population, thus allowing a direct identification, both to the context and the objects that are found and used within it.

Finally, the question of the origin of these objects remains: many from the colonial era, such as the brazier, while others could have incorporated later modifications at a national or regional Latin American level; others may have been imported. Similar questions arise regarding the confrontation of locally manufactured and imported objects where both could be recognizable as part of an imagery identity. 


\section{References}

Baudrillard, J. (1996) The System of Objects, London: Verso.

Charpy, M. (2015) 'How Things Shape Us: Material Culture and Identity in the Industrial Age', in Gerritsen, A. and Riello, G. (ed.) Writing Material Culture History, Great Britain: Bloomsbury.

Csikszentmihalyi, M. and Rochberg-Halton, E. (1981) The Meaning of Things: Domestic Symbols and the Self, Cambridge: Cambridge University Press.

De Ramón, A. and Gross, P. (1985) 'Santiago de Chile: Características histórico ambientales (18911924)', Monografías de Nueva Historia, no. 1, London: University of London.

Eyzaguirre, G. and Errázuriz, J. (1903) Estudio Social. Monografía de una familia obrera en Santiago, Santiago: Imprenta y Encuadernación Barcelona.

García, N. (2013) Culturas híbridas. Estrategias para entrar y salir de la modernidad, $3^{\text {rd }}$ edition, Buenos Aires: Paidós.

Labarca, A. (1939) Historia de la Enseñanza en Chile, Santiago: Universidad de Chile.

Malacchini, S. (2012) 'Lira Popular, Chilean broadsheets from the late nineteenth century. A graphic referent and its relation with sheets from Brazil and México' in Farías, P (coord.) Design Frontiers - Territories, concepts, technologies, Sao Paulo: Blucher.

Malacchini, S. (2015) Lira Popular, Identidad gráfica de un medio impreso chileno, Santiago: Ocho Libros Editores.

Salazar, G. (2000) Labradores, peones y proletariado: formación y crisis de la sociedad popular chilena [Farmers, laborers and proletariat: formation and crisis of popular Chilean society], Santiago: LOM Ediciones.

\section{Biographical note}

Simoné Malacchini is a teacher in the Department of Design, Facultad de Arquitectura y Urbanismo, University of Chile. Author of the book "Lira Popular, identidad gráfica de un medio impreso chileno" (2015). Has also curated the collections of contemporary art "Ojo Andino Chile" (2015) and "Ojo Andino Perú" (2016) part of the Imago Mundi collection; among other works and books. Interested in visual and material culture. 